International Journal of Engineering \& Technology, $7(3.30)(2018) 219-224$
International Journal of Engineering \& Technology
WPC
Website www.sciencepubco.com/index.php/IJET
Research paper

\title{
The Problem of 'Open Price Term' in Contracts of Sale of Goods in Iran and under the United Nations Convention on Contracts for the International Sale of Goods
}

\author{
Farzaneh Akrami ${ }^{*}$, Sakina Shaik Ahmad Yusoff ${ }^{2}$, Suzanna Mohamed Isa ${ }^{2}$ \\ ${ }^{a}$ Islamic Azad University Iran \\ ${ }^{b}$ Faculty of Law, Universiti Kebangsaan Malaysia \\ *Corresponding author E-mail: farzaneh.akrami@yahoo.com
}

\begin{abstract}
This is an undeniable fact is that incomprehensible or restricted rules cause problems for merchants as suppliers. This is more perceptible through domestic rules of the countries. However, international businessmen are also affected by existing conflicts in the international regulations. The concept of 'open price term' in contracts for the sale of goods is one of the best samples for developments in the world's trade. However, regarding the open price term, the Iranian law has yet to adopt this vital phenomenon. On the other hand, if Iranian legislator aims to impose open price rules in the regulations, provisions of an international set of rules seem to be a useful model for such regulations as they are more common and have the capacity of being applied in the contracts made by parties from all over the world. As such, the United Nations Convention on Contracts for the International Sale of Goods (CISG), as an international set of rules containing open price rules is chosen in this paper to be studied as a model for such regulations. However, respective Article in CISG consists of some shortcoming as well. Thus, Adopting the doctrinal research method, in this paper aims to highlight the importance of adopting new rules for new methods of transaction and the necessity of amendments on existing rules.
\end{abstract}

Keywords: Open price; contract of sale of goods; Iranian Civil Code; United Nations Convention on Contracts for the International Sale of Goods

\section{Introduction}

Sale contract is one of the most practiced contracts throughout the world. Business people are directly affected by old regulations that cause different obstacles in their today's transactions. Thus scrutanising the law and legal rules that govern sale contracts is a necessary step that can be taken in favor of merchants and traders. According to Zuluet [1], the necessity attached to the specification for considerations in a sale of goods contract has traditionally been an unavoidable need. For example, in the Roman legal system, a contract is valid only if the exact amount of the price is determined or certain features used to determine the price existed in the contract. Therefore, as Darabpour [2] explains, if the price was to be determined in future by variable factors, or it was devolved to a third party to fix the price, the contract is avoided.

Today, in many jurisdictions, both domestically and internationally due to new circumstances, the issue of price determination has been replaced by the concept of 'open price'. Nevertheless, some countries such as Iran, still insist on retaining traditional methods and seem to be quite resistant when faced with such changes. To Prosser ${ }^{3}$, sale contracts with open price terms are "most commonly made when the market is fluctuating violently, and future prices are most uncertain". In these circumstances, the parties make their sale contract with an open price term to reduce the possibility of contractual risks. Price fluctuation is one of the common examples of contractual risks and is in fact the basic cause of creation of the concept of the open price term. Prosser [3] explains this by mentioning that the parties of a sale of goods contract, seller and buyer, are always concerned about price fluctuations; the seller concerns whether the market price of the goods will decrease if he does not sell the goods now and the buyer is worried about the increase in the price of the goods if he does not buy now. On the other hand, when they form the contract and sell and buy the goods, the above contractual risks are shifted between the parties; now the seller is thinking of the possibility of increase in price of the goods' and that he could have sold them at a higher price, and, the buyer thinks that the price for the goods may decrease and he has now paid too much for the goods. This situation is similar when the goods are for future delivery. Thus, parties may wish to form a safer contract. As such, they leave the amount of the price unfixed to be determined in the future. In this way, any unpleasant changes in price for any of the parties can be compensated by non-payment to insurance institutions to cope with price fluctuation as the price is not fixed in the contract. As Darabpour [4] explains, creation of new trade methods, cause other ways of using the open price term; a manufacturing company may announce that if buyers form a sale contract with the company with an open price term (as the final price is not ascertainable yet) and pay a certain amount (to be counted as part of the final price), then, the product will be delivered to them with a price which is lesser that the market price of the goods at the time of delivery. This is a method through which manufacturers in a country such as Iran with its certain economic specifications can reduce their concerns as to financial needs for production on the one hand, and the existence of any consumers for their products on the other hand.

Recognition of the open price term in Iran can be a significant step in favour of commercial affairs not only in domestic level, but also at the international level. To be more precise, Iranian traders who wish to form an open price sale contract with traders from other 
countries, have no opportunity to attempt to make Iranian law as the law under which the contract is governed in general or in case of any conflict. This is due to the fact that an open price sale contract is not recognised by Iranian law.

At this point, another aspect of this subject crosses the mind: at the international level, where transactors are from different countries of the world with different domestic rules, how open price contracts are governed? In the absence of a comprehensive international law, every deal and contract made in the international area may only be governed by many territorial laws. As such, United Nations Convention on Contracts for the International Sale of Goods (CISG) is created to present an international law for contracts of sale of goods so that parties can choose to appoint it as the regulation that governs the contract. CISG has recognised open price term and has provided certain regulations for it. It has the potential to be applied in all international sale contracts and open price provisions in it can be a good example of such rules. In this way, countries such as Iran can look at it as a sample once it is decided to accept such term in the law of sale of goods.

Considering the above discussions, which carry with it the necessity of amendments and passage from old and traditional rules to modern rules, the next question that arises is whether the existing open price rules are comprehensive and perfectly drafted? This question leads to another fact that not only amendments should be made as to adoption of new concepts in the world, but also the existing regulations on these new concepts need to be amended as well. The reason to choose open price rules in CISG as a sample and model is that CISG is an international set of rules that many countries in the world have ratified it, and, many of contracts of sale of goods are following its rules. In fact, regardless of what the domestic rules of each of these countries are, CISG rules are drafted in a way that can be welcomed by many countries and in considerable numbers of contracts. Thus, if the Iranian law accepts the open price term, perhaps the first model for such regulations that can be looked at can be the rules in CISG.

As such, through following discussions, open price regulation in CISG on the one hand, and current Iranian law on this issue on the other hand are briefly studied. The study shows that even the existing regulations that ought to act as a sample for countries such as Iran, need reconsiderations and amendments. In addition, it shows the negative consequences of rejection of open price term in Iran based on contemporary needs and circumstances and suggests amendments.

\section{Price in a Contract of Sale of Goods Accord- ing to the Law of Iran}

In discussing Iranian law, it is necessary to start with a brief history of Iranian law to describe how such law was established and shaped. On Tuesday, 31 December 1927, a Board comprising of Shari'ah and non-Shari'ah legal experts was appointed and began drafting the Civil Code of Iran. The majority of the latter group had studied law in universities of foreign countries especially France. At that stage, the main effort of the legislators of the Iranian Civil Code was to write the rules on Causes of Title, Types of Property, Generalities of Contracts, Contractual and NonContractual Liability. Their effort resulted in the first volume of the Iranian Civil Code, consisting of 955 Articles, which was enrolled on 8 May 1928. Other parts of this code were enrolled in 1934 and 1935. The Civil Code was completed with 1335 Articles [5].

The two main sources that were used to write this code, particularly the first volume containing rules for sale contracts, are Shari'ah law and foreign law, significantly, the law of France. Articles under the title of 'Defined Contracts' (Chapter 3, Section1(1), Articles 338-824) in which sale contract is the first described contract, are obtained from Shari'ah law although they followed foreign rules in the method of writing and portioning. This is because many of these rules, particularly French law, are to some extent similar to Islamic rules, and this similarity could be one of the main reasons for choosing it as a source [4].

Through Islamic law of sale of goods, in order to prevent parties from contractual risks and any financial loss (qarar), parties to the contract must know all the specifications of the goods and the price. In this way, the buyer knows how much is he going to obtain through the contract and the seller knows how much he has to pay and what will he receive in return. The principles under which fixing the price by the time of formation of the price is emphasised are Islamic principles of 'prohibition of a harmful sale contract' and 'prohibition of any loss and any causes of loss in Islam'. To discuss the justifications for acceptance of open price term in Islamic law and the fact that based on today's trade methods, rejection of the open price term is contrary to the above mentioned principles is a topic that needs to be discussed separately and precisely. In this paper, as the aim is to highlight the negative consequenses of rejection of open price term in Iran, the main emphasis will be on practical obstacles for traders although a brief explanation on acceptability of open price term through Islamic law will also be provided.

'Sale of Goods Contract' is a title in the Iranian Civil Code that is started by Article 338. This Article explains that: "a sale contract consists of the transfer of the subject matter of the contract in return for a definite consideration". This Article defines sale contract and is an imperative rule. Thus, the parties can not agree contrary to the contents of it, otherwise the agreement is not supported by the law. Hence, as it is stipulated in the Article, the parties who want to conclude a sale contract should specify the goods and its price; thus, only in this way can the contract be concluded. In line with the above details, Article 339 provides that "after determination of the object of the bargain and its price by the seller and the buyer, the sale is concluded by offer and acceptance." As Katouzian [6] explains, the imposed rule in this Article is that the agreement on goods and its price should take place earlier than when the contract is formed and the contract will not legally exist if the price is vague or unsure. Thus, parties should know the amount and specifications of it [7]. Under the Iranian law, it is not enough that the price is capable to be determined; the amount of price ought to be clear for the parties when the contract is being formed [8].

Although parties that are willing to form a sale contract can appoint a third party to fix the contractual price, however, as Katoozian [9] points out, such an agreement will be recognized as a concluded sale contract only after the third party fixes the price. Before the third party determines the price, there is only a precontractual agreement. To answer the question that can Articles 338 and 339 be interpreted in a way that open price term be authorised, Deilami [10] states that Articles 338 and 339 of the Civil Code are imperative Articles that judges cannot decide contrary to them. On the other hand, an Article can be interpreted only if it is not explicit in what it states and there are some vague or debatable point that permits judges and lawyers to interpret it. According to law, there are some specific situations in which rules can be interpreted, such as incomplete law, brevity and ambiguity, conflict of laws and lack of laws [11] Unfortunately according to the Persian literature, the above mentioned Articles are completely clear.

As to Article 339, Emami [12] notes that when this Article has no additional provision about an open price term in the codification, a contract concluded in any way other than the specification of the consideration before the time of the formation of the contract, is void and unrecognisable by law. The price should be determined and specified by the parties; otherwise it would be damaging and void. Why do the parties need to be aware of the specifications of considerations? This is generally in favor of the public peace and more specifically based on the legal and Islamic principle iposing that lack of awareness will cause loss for the parties. This is similar to the need for certainty that is required in other legal systems. The factors that can affect the parties' wish and will for entering into a contract should be clear and exact. By specifying the price, 
no vague subject will exist in the contract that may affect the interests of the parties and cause future disagreements.

However, there exists a dilemma among scholars. In fact, there are other ideas among the writers and legal experts as well; some of the experts who know about developments, worldwide changes in trading methods and the needs of the merchants and transactors in specific situations, believe in the necessity of amendments in the regulations in a way that parties to a sale of goods contract have the possibility to form an open price contract whenever desired [13]. According to traditional attitude of Iranian law, undetermined price will cause the parties to incur losses and therefore, the contract is illegal. However, nowadays, in certain situations, parties benefit from open price term sale contracts as they know they will face lesser contractual risks [14]. Poursaber [15] argues that considering the reason for rejection of the open price term, which is prevention of loss of the parties, a reasonable counter evidence for the efficiency of this term could be the numerous sale of goods contracts that are formed throughout the word. Parties of such contracts, choose to form the contract with an open price term. In these contracts, parties benefit from the open price term and to leave the price open, is a method which is chosen by the parties in order to benefit from the contract as much as possible and to avoid contractual risks.

This is the point for acceptation of open price term in Islamic law. In fact, the aim for Islamic principles is to protect parties from any financial loss. This aim could be achieved by making the parties to specify all the details and the amount of the price by the time of formation of the contract. However, this rule was effective only in the traditional methods of trade. The complicated trade methods in today's business and commerce does not tolerate such restricted rules and in fact, this kind of rules will act as the main basis for parties' financial loss. As such, based on current trends and circumstances, and in order to enforce and respect the goals of the above mentioned Islamic principles, the parties should be free to form open price sale contracts once they believe that it would be more beneficial for them and it will reduce contractual risks.

An obvious consequence of rejection of open price sale contracts is that the law does not respond to the needs of the country's economy and business such as economic improvements, boosting of manufacturing activities and in turn hinders increased national production of better quality, investment promotion and job creation. Considering the above mentioned way in which an open price term can affect manufacturers' business as an example, it is understood that the deposit received by manufacturer from buyers by the time of formation of the contract can act as a part of the needed capital in order to start production. The existence of such money will help producting in higher amount and better quality. The open price term itself is a reliable document for manufacturers as to certainty about existence of consumers of the products. This is of the best motivations for continuing productions. On the other hand, when the manufactory is active and productive, it will be able to support its employee and labor, otherwise, the possibility for them to lose their jobs would be higher. In fact, the rejection of open price term has caused problems at two levels, namely transactional and national levels [4]. Business people sometimes do not wait for the permission of the law and conclude open price contracts in order to satisfy their commercial needs, even if such contracts are not supported by courts in case of any dispute [15]. In addition, Iranian rules and law can only be interpreted through Islamic principles in such circumstances. Reference to Islamic law by Iranian judges will not change the rules as the open price term is considered a harmful term for the parties and is thus refused ${ }^{11}$. Based on religious jurisprudence, the principle of 'prohibition of any grounds of loss' is used as a benchmark and a criterion for distinguishing the accuracy and inaccuracy of different subjects [28].

Due to the current state of Iranian law on open price term, a considerably important group of sale contracts that in today's economic circumstances play a principal role and are well practiced in most of the other countries, cannot be concluded in Iran. Some of these occasions are mentioned below:

Prudent buyers and sellers do not want to take the risk of increase or decrease in the price of the goods in the period between the time of formation of the contract and when the goods are delivered. Such far-sighted parties are not free in their deal; they are actually restricted by the inflexible rule in Iran.

In long-term contracts where the price of future goods is not specified, if by any reason parties present the contract in court, the court will usually consider that part of the contract pertaining to future goods and price determination, as a pre-contractual agreement, not a sale contract [8].

Noori [16] points out that manufacturers need open price sale contracts in order to certify the number of purchasers in order to afford some parts of production expenses by receiving some deposit. It is a fact that the manufacturing sector forms a vital foundation for a country's economy. Social needs, contractual profit, the lack of loss in trading through open price contracts, transaction speed and reliability of the conclusion of the contract are essential in businessmen's commercial life. The aforementioned coupled with ongoing work in factories are all the positive consequences of the acceptance of open price term in domestic rules. As it was explained earlier and based on the above mentioned idea of scholars, accepting open price term causes increase of investment and production at the national level which will lead to economic development opportunity for the country. Unfortunately, Iran's approach to the matter of price in a sale contract brings serious hardships to merchants and manufacturers [17].

It is now clear that the Iranian law has not accepted open price term and this seems to be a disadvantage of this legal system. However, as explained earlier, existing legislations on open price that can act as a guideline and model for open price rules contain shortcomings and negative points themselves. This unpleasant fact highlights the necessity and need for amendments and reconsiderations in such rules as a priority. Open price regulation in CISG for example, that in this paper acts as a model for such rules contains certain negative points in it. As such, certain points and issues in Article 55 of CISG through which open price term is regulated will be studied in this paper as well.

\section{United Nations Convention on Contracts for International Sale of Goods (CISG)}

Contrary to what is stated in a court decision (CLOUT case No. 201, [Richteramt Laufen des Kantons Berne, Switzerland, 7 May 1993]) as to CISG to be "an exhaustive body of rules," and an efficient set of rules, in some parts, it contains certain shortcomings ${ }^{17}$. Regarding Article 55 of this set of rules, some aspects and issues are missing or not comprehensively mentioned [18]. To start the discussion on Article 55, the first thing to be mentioned will be the conflict between this Article and Articles 14 (1) of CISG. These two articles, once are looked at simultaneously, are two conflicting and debatable texts to the extent that some writers have attempted to tackle the situation to find an efficient result. Under the title "Formation of The Contract" in CISG, Article 14(1) expresses that:

(1) A proposal for concluding a contract addressed to one or more specific persons constitutes an offer if it is sufficiently definite and indicates the intention of the offer or to be bound in case of acceptance. A proposal is sufficiently definite if it indicates the goods and expressly or implicitly fixes or makes provision for determining the quantity and the price.

In part (1) of this Article, it is clear that price needs to be determined at the time an offer for sale is made. In other words, the offer should contain the amount of price, either, expressly or implicitly, or at least, there should be sufficient provision for determination of the price. Contracts are built on two unavoidable bases, namely 'offer' and 'acceptance'; a defective offer will result in the impossibility of formation of a legal contract. As Amato 
[19] explains, this Article expresses that a proposal should be sufficiently definite and an offer in which the price has not been mentioned, is not a definite proposal. Thus, a sale contract in which the parties have made no attempt to fix any price, seems to be rejected through this Article of CISG.

However, Article 55 represents the possibility of formation of a legal contract without specifying the amount of the price. This Article provides:

Where a contract has been validly concluded, but does not expressly or implicitly fix or make provision for determining the price, the parties are considered, in the absence of any indication to the contrary, to have impliedly made reference to the price generally charged at the time of the conclusion of the contract for such goods sold under comparable circumstances in the trade concerned.

The existence of both Articles 14 and 55 simultaneously in CISG seems questionable. As Amato [19] describes, on this issue, two different points of view exist that were initiated by Honnold and Farnsworth; Amato explains that based on Honnold's viewpoint there is no conflict between the two Articles. Honnold justifies his opinion by explaining that in cases where the parties leave the price open, Article 55 considers the parties have "implicitly made reference to the price generally charged... ."

Mistelis (2005-2006) [20] follows this idea as he explains that based on Article 14, the price should be expressly or implicitly fixed and this is what Article 55 agrees with. The combination of these two facts will result to a harmony between the Articles rather than a conflict. In other words, through this reasoning, the requirement of Article 14 in which the price should be at least 'implicitly' fixed, will be answered as Article 55 which provides that the open price term fixed implicitly as 'price generally charged at the time of conclusion of the contract'. Based on Article 14(1), if the parties have not implicitly fixed the price, then there is no legal offer. However, Article 55 provides that if the parties have not even implicitly fixed the price, then they are assumed to have impliedly fixed the price generally charge. As such, the fact is that the conflict is still there and although this kind of reasoning is useful for the parties as it helps to uphold the contract, However, it is just a solution given to the courts and the parties, whereas a fundamental amendment of these Articles is essential. On the other hand, Farnsworth [21] has the contrary viewpoint in this regard. He contends that there is no way the two Articles can be reconciled. In his opinion, according to Article 14(1), if the parties do not agree on the price and are quiet about it, then the offer is not sufficiently definite and therefore there will not be any contract. He believes that based on the first sentence of Article 55, there should be a validly formed sale of goods contract to impose the provisions of Article 55 on [22]. In other words, to Farnsworth, Article 55 which is located in Part III of CISG will be useful only if the contracting state, subject to Article 92(1) of the convention, has declared that it will not be bound by Part II of the Convention in which Article 14(1) exists. In view of this, the domestic rules of the contracting countries play a significant role. If the domestic sales law of the country accepts open price term, then the open price sale contract made by the parties is valid. In such a case, Article 55 can be applied in order to fill the price term. However, if the domestic sales law of the country has not ratified the matter of open price term in sale contracts, then the contract is not a valid deal and consequently, Article 55 cannot be applied [20]. This reasoning sounds like a proposal for amendments on Article 55 by adding a phrase such as 'for contracts made by parties from countries that have declared not to be bound by Part II of the convention, ....' Otherwise, there is no actual proof for what he claims.

Following the above opinions, the next question will be whether these two Articles should be utilised together or as Farnsworth points out, are they created for separate conditions? For some, the answer is whether or not based on Article 14(1) a proposal that does not specify price is regarded as an 'offer'. For the rest, it was whether or not a proposal which does not contain any fixed price or a condition to fix it later is a 'valid' and binding action [22].
Honnold [23] argues that the answer which is given by each expert reflects his country's domestic law. In one lawful society, it is felt that a contract of sale, must normally provide the price; in another lawful society, broader methods and ways of formation of the contract is provided.

This apparent conflict between the two Articles has led the courts to decide differently in almost alike cases and this is a significant negative point for such regulations. In order to give an example as to how differently the two Articles are used by judges, two court decisions, both in Hungary, one for Supreme Court and the other for preliminary court, are mentioned in below. In Pratt \& Whitney v Malev (CLOUT case abstract No. 53) in 1992, the Supreme Court of Hungary held that the offer that had been made by an American manufacturer of aircraft, did not have the sufficient elements of a valid offer as it did not contain the price of the goods (engines) and consequently there was no binding contract based on Article 14(1). This is a decision that authorises the idea that the two Articles are not competing each other and are not to be read together. Based of this decision, the contract is avoided as it has not specified the price which is contrary to Article 14 (1). However, in the same year in Adamfi Video Production GmbH v Alkotók Studiósa Kisszövetkezet (Fovárosi Biróság Metropolitan Court (Hungary) No: 12.G.41.471/1991/21) the court's effort was to uphold the contract between the parties. In fact, the court believed that the offer made by a German seller was sufficient to make an offer, although there had not been a price stated. In this case it was held that the price was not expressly but implicitly set as the parties had a number of transactions and business relations of the same kind; the seller had sold and delivered the same kind of goods to the buyer and the buyer had paid for the delivered goods several times.

Another decision was made in 1997 in a court in Switzerland (CLOUT case No. 215 [SWITZERLAND Bezirksgericht [District Court] St. Gallen 3 July 1997]) as to a sale contract in which the price was left open. In this case, contrary to the above mentioned case, the court upheld the contract and specified a price for the goods sold through the contract. This decision was made based on Article 55 that expressly allows open price term. Equally, in another case determined in 1999 by way of arbitration, the arbitrators believed that the existence of Article 55 shows that transactions without former settling of the price is normal in the world's trade. Thus, the tribunal recognised the contract and determined the price itself. (CLOUT case abstract No. 9819 of 1999).

Bernstein [24] and Lookofsky [25] argue that based on Article 14(2) in which it is stated that "a proposal ...constitutes an offer if it ... indicates the intention of the offeror to be bound in case of acceptance", courts and arbitrators ought to first find out the intention of the parties when entering into the contract. In addition to Article 14(2), the convention has other provisions such as Article 6 declaring that the parties are legally able to "derogate from or vary the effect of any of its [(CISG)] provisions." As such, parties are able to derogate from Article 14 (1) as well. Nevertheless, finding out the real intention of the parties is also another complicated issue especially where in times of any dispute, each party will usually make an effort to turn all the evidences in his own benefit.

Conflicting court decisions and the existing uncertainty as to the governing rules on open price sale contracts elaborate the need for amendments in CISG. The contradiction between Articles 14 and 55 has also led to conflicting interpretations. Lawyers have very different ideas as to the way of dealing with these two conflicting Articles. This is a problem that is worsened by the fact that these regulations are supposed to be exercised in a worldwide scale. Obviously, this issue should be counted as a negative point and a disadvantage in CISG and ought to be urgently amended.

Another issue in Article 55 is the way in which open price is defined. In this Article, it is stated that, "where a contract has been validly concluded but does not expressly or implicitly fix or make provision for determining the price, the parties are considered ... to have impliedly made reference to the price ...". This provision 
creates a question as to whether other ways of agreement between parties will fall outside of it? In other words, if the parties have implicitly determined the price, or, if they have agreed on certain methods of fixing the price but, later as a result of some issues, they will not be able to determine the price through the agreed method, then, will this kind of agreement be governed under the provisions in Article 55?

According to Article 55 of CISG, the proposed price is, "the price generally charged at the time of the conclusion of the contract for such goods sold under comparable circumstances in the trade concerned." Through this statement, Article 55 attempts to provide some guidelines for the courts as to what a reasonable price could be and this is an obvious advantage of this regulation. However, one of the disadvantages of the provision should be considered at this point. According to Edwards and Cindy [26], the motivation behind why transactors may utilize an open price term is to maintain a strategic distance from any contractual risk that is sometimes created by price fluctuation. This is the primary motivation behind why parties are typically unwilling to follow the market price of the goods at the time of conclusion of the contract.

They prefer not to fix the price until the merchandise are prepared and are delivered. As such, contractual price will be the price of the goods at the time of delivery. However, although the parties have initially left the price open to avoid the price of the time of formation of the contract, it is questionable that the provision in Article 55 suggests that once the price is to be fixed by courts, they specify the price of the time of conclusion of the contract Mistelis [20] points out this issue by arguing that it is hard to accept that the legislators have not considered the situations in which the parties have left the price open with the reason that the price at the time of conclusion of the contract will not be beneficial to them. This issue seems unusual to him to the extent that he gives an example of a situation where, "the parties have contracted with the intention to create a long-term contract that recognizes the changes that occur over time to the pricing of the goods." In order to overcome this situation, he suggests that such assumption in Article 55 (time of the conclusion of the contract) can be treated as a rejectable presumption [20]. To Benjamin and Bridge [27] the reasonable price of goods is, "usually ascertained by reference to the current market price at the time and place of delivery." Normally, if the parties intend to use the price of the time of contracting, they would not leave it open. In addition, if they aimed to use such price, they would not specify any method for determination of the price in the future. Based on the above discussions, it seems not to be a helpful suggestion from the Articles to the courts to specify the price of the time of formation of the contract. As such, this is another issue to be considered as a part of CISG to be reconsidered.

Finally, it should me mentioned that there are few matters that are separately regulated in some codifications such as Uniform Commercial Code of the Unites States and the Sale of Goods Act 1979 of the United Kingdom but not in CISG. Determination of the price by a third party and impossibility of determination of the price due to fault of one of the parties of the contract, are of such matters. In above mentioned sets of rules, impossibility of price fixing through evaluation of a third party is considered as a different issue compared to other methods. However, it seems that the attitude of CISG in this issue seems more reasonable. In other words, like CISG, to consider it simply as one of the different methods of price fixing and not to mention in separately sounds logical as no significant specification seems to be attached to this method.

As to the issue of fault of one party, however, it is worth to be considered truly when regulating open price term in a codification. And this is another point to be considered in CISG. It is possible that in case of impossibility of determination of price due to fault of one of the parties, domestic rules of the countries, depending on each case, be applied to the contract unless there is any special agreement between parties as to this situation.

\section{Conclusion}

The existence and recognition of the 'open price term' in sale contracts has brought about a considerable change in the traditional rules which makes the commercial affairs of business people easier. Thus, in a safe, economic environment, the quality and quantity of the goods produced by manufactories will improve and increase. Traders will benefit much more from their transactions and contractual risks will be reduced. The creation of open price sale of goods contracts was due to the global and consequently, domestic changes in trade methods, which, required updated regulations. However, Iran has not recognized this useful term in sale contracts and this has caused difficulties at national and transactional levels. National production and international trades between Iranian businessmen and other countries are of two important fields that can be negatively affected by such rejection of open price term. The fact that this rejection is sourced from Islamic principles also will not justify the rejection of open price is based on the main goal and purpose of the Islamic principles, benefits and rights of the parties should be protected whilst rejection of open price will cause financial loss and contractual risks to the parties. As such, acceptance of open price term is a necessity for the Iranian law. On the other hand, CISG as an important international set of rules has mentioned the issue of open price. Thus, in order to perform any amendments in the Iranian law and to accept open price, the regulations of CISG can act as a model and sample. This is especially due to the fact that CISG's provisions are accepted by many countries and have a common nature. However, CISG also contains different shortcomings that have made it necessary to be amended. Such revisions and amendments of the laws and rules, will show the urgent need for revisions and amendments in the laws and this will directly result in improvements in countries' and world's trade circumstances.

\section{References}

[1] Zuluet FD (1945), The Roman Law of Sale. Oxford: Clarendon.

[2] Darabpoor M (1995), An Interpretation on International Sale Law. Tehran: Ganjedanesh.

[3] Prosser WL (1932), Open price in contracts for the sale of goods. Minnesota Law Review 16(7), 733-790.

[4] Darabpoor M (1998), Open price. Tahghighat Hoghooghi 21-22, 221-283.

[5] Bahrami HA (2005), History of Civil Code legislation. Imam Sadeq University Research Quarterly 24, 33-55.

[6] Katoozian N (2012), Introduction to Law. 81. Tehran: Enteshar.

[7] Katoozian N (1996), General Rules of Contracts. Tehran: Enteshar \& Bahmanborna.

[8] Katoozian N (2006), Course of Defined Contracts; Civil Law. Tehran: Enteshar.

[9] Katoozian N (1997), Course of Civil Law Lessons from Defined Contracts. Tehran: Ganjedanesh.

[10] Deilami A (2004), Requirements for Interpretation of Rules. Qom: Qom University Publication.

[11] Baroonians A (1953), Methods of interpretation of civil rules. Bar Association Journal 35, 31-38.

[12] Emami S H (1996), Civil Law. Tehran: Eslamiyeh.

[13] Shahidi M (1993), Formation of the Contracts and Obligations. Tehran: Hoghooghdan Publication.

[14] Akrami F, Sakina Shaik Ahmad Yusoff \& Suzanna Mohamed Isa (2015). Open price for Iran: The bases for reform. Mediterranean Journal of Social Sciences 6, 166-174.

[15] Poursaber B (2010), Open price. Azad University Law Quarterly $11,11-22$.

[16] Noori SM (2000), Sale contract with open price according to the Islam rules. Nameh Mofid 22, 33-70.

[17] Ferrari F (1998), Implementations of the Convention on Contracts for the International Sale of Goods (CISG) [Notes]. International Business Law Journal 1998(7), 835-839.

[18] Anon (2012) United Nations Commission on International Trade Law Digest of Case Law on the United Nation Convention on the International Sale of Goods. United Nations Publication: New 
York. Available at: http://www.uncitral.org/pdf/english/clout/0851939_Ebook.pdf (visited 19 Oct 2013).

[19] Amato P (1993), U.N. Convention on Contracts for the International Sale of Goods - the Open price Term and Uniform Application: An Early Interpretation by the Hungarian Courts. Journal of Law and Commerce 13, 1-29.

[20] Mistelis L (2005-2006), Article 55 CISG: the unknown factor Journal of Law and Commerce 25(1), 285-298.

[21] Farnsworth AE, (1984), The Vienna Conventions history and scope. International Law Journal, 18, 17-20.

[22] Honnold JO (1986), Uniform law for international trade-progress and prospects. International Lawyer, 20, 635-639.

[23] Honnold JO (1984), New uniform law for international law for international sales and the UCC: A Comparison. International Lawyer $(A B A), 18(1), 21-28$

[24] Bernstein H \& Lookofsky JM (2002), Understanding the CISG in Europe. Kluwer Law International: England.

[25] Lookofsky JM, Bridge M, Viscasillas, MDPP, Erauw J, Gabriel, H, Garro A, Volken P, Brand RA, Ly FD, Arcevic PA, Murray JE, Magnus U, Ferrari F \& Flechtner H (2003), The Draft Uncitral Digest and Beyond: Cases, Analysis and Unresolved Issues in the U.N Sales Convention. London: European Law Publisher.

[26] Edwards FR \& Cindy WM (1992), Futures \& Options. Singapore: Mc.Graw Hill.

[27] Benjamin JP, Bridge MG, Bennett H, Dawson F, Lomnicka E, Miller CJ, Rawlings P, Reynolds FMB \& Treitel G. (eds). (2010), Benjamin's Sale of Goods. London: Sweet \& Maxwell.

[28] Morvarid AA (1993), Selselah Al-Yanabiô Al-Feqhiah. Beirut: Feqh Al-Shi'ah. 